\title{
UWAŻNOŚĆ I JEJ POMIAR
}

STANISŁAW RADON *

Uniwersytet Papieża Jana Pawła II, Polska

\section{STRESZCZENIE}

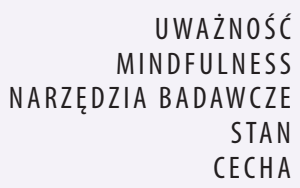

Uważność może być rozumiana jako stan lub cecha. $Z$ tego powodu istnieje wiele niejasności, które wynikają głównie z braku precyzji dotyczącej zakładanego modelu uważności. Podobne rozbieżności dotyczą stosowanych narzędzi badawczych służących do pomiaru nasilenia uważności. Jak dowodzą liczne badania, narzędzia te mierzą nieco odmienne konstrukty psychologiczne. Dlatego badacze coraz częściej podejmują próby wyróżnienia oraz bardziej precyzyjnego rozdzielenia dwóch odmiennych aspektów uważności, tj. cechy i stanu, oraz opracowania na tej podstawie bardziej trafnych narzędzi badawczych. Niniejszy artykuł to przegląd istniejących miar uważności, z uwzględnieniem polskich adaptacji i ukazaniem ich specyfiki.

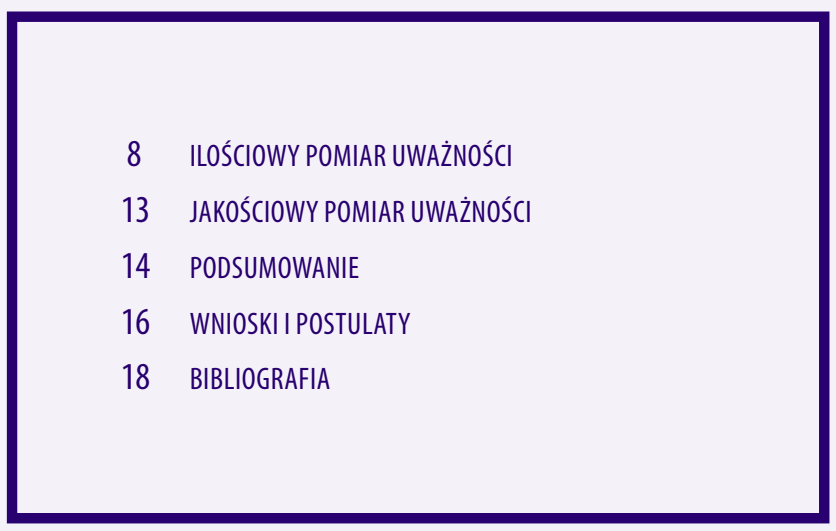




\title{
MINDFULNESS AND ITS MEASUREMENT
}

\begin{abstract}
Mindfulness can be understood as a state, trait or practice. For this reason, there are many uncertainties that result mainly from the lack of precision regarding the mindfulness model. Similar ambiguities exist in the field of research tools to measure the mindfulness. As many researchers prove, these tools measure slightly different psychological constructs. For this reason researchers attempt to distinguish two different aspects of mindfulness, the trait and state, and on this basis develop more accurate research tools. This article is a review of existing measures of mindfulness, taking into account Polish adaptations, showing their specificity.
\end{abstract}

\section{KEYWORDS}

mindfulness, research tools, state, trait 
D: o tej pory opublikowano wiele badań oraz metaanaliz dotyczących specyfiki, typologii, struktury uważności oraz efektywności stosowania interwencji opartych na uważności (por. Radoń, 2017a; 2020). Wynika z nich wyraźnie, że systematyczne praktykowanie uważności wpływa pozytywnie na pojawianie się istotnych zmian w zakresie procesów kognitywnych, afektywnych i behawioralnych (Sedlmeier i in., 2012) oraz struktury i funkcji mózgu (Cahn, Polich, 2006; Fox i in., 2014; Xue i in., 2014). Jednak pomimo tak wielkiej liczby przeprowadzonych badań istnieje wiele niejasności, które wynikają głównie z braku precyzji dotyczącej zakładanego w badaniach modelu uważności (stosuje się zróżnicowane protokoły treningowe). Ponadto brak jest badań, które syntetyzowałyby uzyskane rezultaty badawcze w zakresie narracyjnym (Rubia, 2009; Tang, Hölzel, Posner, 2015), metaanalitycznym (Fox i in., 2014; Sedlmeier i in., 2012) i teoretycznym (Hölzel i in., 2011; Vago, Silbersweig, 2012).

Najczęściej cytowana definicja uważności określa ją jako szczególny stan uwagi celowo kierowanej na chwilę obecną, bez osądzania i oceniania (Kabat-Zinn, 1990). Pomimo ogólnej zgody badaczy na tak definiowane pojęcie uważności istnieje wiele jej egzemplifikacji, podkreślających różne jej aspekty (pojęcie „parasol”; por. Sperduti, Martinelli, Piolino, 2012). Uważność pojmowana zgodnie z przytoczoną definicją obejmuje takie mechanizmy jak: ostrzenie i podtrzymywanie uwagi (Wallace, 2006), poprawianie regulacji emocji i dobrostanu (Chambers, Gullone, Allen, 2009; Sedlmeier i in., 2012), wizualizacja (Kozhevnikov, Louchakova, Josipovic, Motes, 2009) oraz pogłębianie współczucia wobec innych (Galante, Galante, Bekkers, Gallacher, 2014).

Niejasności wynikają głównie z tego, że omawiany obszar badań jest trudny do empirycznej eksploracji. Dotyczy bowiem tzw. wyższych czynności umysłowych, do których obserwacji, kontroli i weryfikacji danych introspekcyjnych osób poddanych badaniom nie mamy odpowiednich narzędzi, umożliwiających ponadto skorelowanie ich z pomiarami empirycznymi (Bitbol, Petitmengin, 2013; Walach, 2014). Trudności dotyczą zwłaszcza osób zaawansowanych w medytacji albo stosujących odmienne techniki medytacyjne (Radoń, 2020).

Wspomniane niejasności odnoszą się zarówno do narzędzi badawczych opartych o autodeklaracje - ilościowych, jak i do jakościowych (Grossman, 2011; Medvedev, Krägeloh, Narayanan, Siegert, 2017; Soler i in., 2014). Wiele stosowanych skal nie charakteryzuje się dobrymi wskaźnikami psychometrycznymi (problemy ze spójnością wewnętrzną, brak trafności zbieżnej z innymi wskaźnikami psychologicznymi, brak trafności zbieżnej między różnymi skalami itd.; por. Grossman, 2011). Problemy te wiążą się z faktem, że skale te prawdopodobnie mierzą nieco inne konstrukty psychologiczne (jedne z nich odnoszą się do cechy uważności, a inne dotyczą umiejętności ćwiczonych podczas praktyk medytacyjnych; jedne odnoszą się bardziej do źródłowych koncepcji uważności, np. medytacja miłującej dobroci/współczucia, a inne do modelu klinicznego itd.; Medvedev i in., 2017; Soler i in., 2014). 


\section{ILOŚCIOWY POMIAR UWAŻNOŚCI}

Do pomiaru uważności opracowano do tej pory wiele kwestionariuszy. Choć mają one podobny cel i opierają się o podobne zasady pomiaru, to jednak istotnie różnią się pod względem zakresu oceny uważności. W konsekwencji mierzą inne cechy psychologiczne.

\section{MINDFUL ATTENTION AND AWARENESS SCALE (MAAS)}

Mindful Attention and Awareness Scale (MAAS; Brown, Ryan, 2003; polska adaptacja: Radoń, 2014a) to jeden z pierwszych kwestionariuszy służących do pomiaru uważności; składa się z 15 pozycji. MAAS powstał w oparciu o doświadczenia zaawansowanych nauczycieli medytacji (buddyzm) oraz innych osób zaawansowanych w treningach uważności. Opracowana na tej podstawie pula 184 pozycji odnosiła się do różnic w poziomach skupiania uwagi na wykonywanych zwykłych czynnościach (chodzenie, jedzenie, prowadzenie samochodu itd.) oraz na towarzyszących im myślach, emocjach i stanach fizjologicznych. Celem tak przygotowywanego kwestionariusza był pomiar wpływu praktyk medytacyjnych na cechy psychologiczne (aktualnie jedyny taki kwestionariusz). Należy podkreślić, że żadna z pozycji MAAS nie odnosiła się do jakichś szczególnych technik wzmacniania uwagi czy świadomości, ale do trwałych predyspozycji psychologicznych (uważność jako cecha).

Tak przygotowaną pulę pozycji poddano procedurom walidacyjnym. Adekwatność każdej pozycji najpierw oceniali kompetentni sędziowie. Ponieważ wyniki badań walidacyjnych pokazały, że pula 184 pozycji zbyt silnie koreluje z pozycjami akceptacji, zdecydowano się na skrócenie testu. Do ostatecznej wersji kwestionariusza wybrano pozycje o wysokich współczynnikach trafności treściowej (ostateczna wersja składa się z 15 pozycji). Wyniki analiz statystycznych uzyskanych podczas badań walidacyjnych wykazały, że wszystkie pozycje MAAS tworzą jeden czynnik (Brown, Ryan, 2003). Wprawdzie są takie badania, które wykazują dwuczynnikową strukturę MAAS (Cebolla, Luciano, DeMarzo, Navarro-Gil, Campayo, 2013), jednak jak stwierdzili autorzy skali drugi obok obecności czynnik, nazwany pierwotnie akceptacja, nie wnosił nic ponad to, co zawierał już czynnik obecność (Brown, Ryan, 2003).

Polska adaptacja (Radoń, 2014a) okazała się narzędziem badawczym o dobrych wskaźnikach psychometrycznych, porównywalnych do oryginału $(N=$ 410: 128 uczniów Zespołu Państwowych Szkół Plastycznych w Krakowie w wieku od 15 do 19 lat oraz 282 studentów Uniwersytetu Papieskiego Jana Pawła II w wieku od 20 do 50 lat). W adaptacji potwierdzono zarówno rzetelność, jak i trafność danych empirycznych do modelu jednoczynnikowego, ale tylko w przypadku osób będących w wieku od 20 do 50 lat). W przypadku osób młodszych trafniejszy był model dwuczynnikowy.

\section{TORONTO MINDFULNESS SCALE (TMS)}

Toronto Mindfulness Scale (TMS; Lau i in., 2006; polska adaptacja: Radoń, Górska, 2020, nieopublikowane badania) - w przeciwieństwie do MAAS nie odnosi się do cechy, ale stanu uważności. Kwestionariusz ocenia bowiem te cechy umysłowe, które są osiagane bezpośrednio przez formalne praktykowanie uważności. Pozycje skali zostały wybrane z dużej 
puli odpowiedzi w ten sposób, aby najlepiej różnicowały osoby doświadczone w medytacji od osób z małym albo żadnym doświadczeniem w tej dziedzinie.

Głównym celem kwestionariusza jest ocena efektywności interwencji opartych o uważność w stosunku do osób cierpiących na zaburzenia emocjonalne. Szczególnym celem TMS jest pomiar zdolności osób cierpiących na zaburzenia emocjonalne do powstrzymywania się od kognitywnych elaboracji doświadczeń (ruminacje dotyczące przeszłości i martwienie się co do przyszłości), zdolności utrzymywania ciągłej uwagi na wewnętrznych doznaniach i myślach oraz poziomu reaktywności na te bodźce.

Badania walidacyjne $(N=390)$ wykazały, że TMS charakteryzuje się dobrymi właściwościami psychometrycznymi. Dobre dopasowanie danych empirycznych do modelu dwuczynnikowego (ciekawość i decentracja) uzyskano po ograniczeniu liczby pozycji do 15 $\left(\chi^{2}(64)=138,24 ; \mathrm{CFI}=0,92 ; \mathrm{NNFI}=0,94\right.$; Lau i in., 2006). Wewnętrzna zgodność jest bardzo wysoka $(\alpha=0,95)$, a trafność wewnętrzna i zewnętrzna są zgodne z założeniami teoretycznymi (Lau i in., 2006).

Przeprowadzone w Polsce badania walidacyjne (Radoń, Górska, 2020, nieopublikowane badania) potwierdziły rzetelność (dokładność mierzenia), jak i trafność (mierzy stan uważności). Próbę badawczą stanowiło 330 osób w wieku od 16 do 67 lat $(M=32,60$; $S D=9,75): 27,2 \%$ osób bez doświadczenia medytacyjnego oraz $72,8 \%$ z doświadczeniem medytacyjnym (modlitwa, medytacja chrześcijańska, joga, medytacja buddyjska, uważność i inne). Osoby były kontrolowane pod względem długości praktykowania (poniżej jednego roku, od roku do 10 lat, powyżej 10 lat), częstotliwości praktykowania (sporadycznie, parę razy w tygodniu, codziennie) oraz długości dziennego zaangażowania w praktykowanie (do pięciu minut, od pięciu do 10 minut, powyżej 10 minut). Potwierdzono dobre dopasowanie danych empirycznych do dwuczynnikowego modelu równorzędnego $\left(\chi^{2}(64)=78,83\right.$; CFI $=0,96 ;$ TLI $=0,95 ;$ RMSEA = 0,056 [0,038-0,074]; PCLOSE = 0,26).

\section{FREIBURG MINDFULNESS INVENTORY (FMI)}

Freiburg Mindfulness Inventory (FMI; Walach, Buchheld, Buttenmüller, Kleinknecht, Schmidt, 2006; polska adaptacja: Radoń, 2017b) to inny kwestionariusz do pomiaru uważności, który tworzy jeden czynnik, chociaż jego teoretyczna struktura jest zdecydowanie bardziej kompleksowa. Na FMI składa się 30 pozycji, które zostały opracowane w oparciu o opinie osób doświadczonych w medytacji wglądu Vipassana dotyczące koncepcji uważności. Pozycje te zostały przyporządkowane do czterech czynników: (1) dezidentyfikująca się od ja świadomość bieżącej chwili; (2) nieosądzająca, nieoceniająca postawa wobec siebie oraz innych; (3) otwartość na negatywne stany umysłowe; (4) rozumienie wglądowe zorientowane na proces. W związku z tym FMI można traktować jako test, który ocenia nasilenie uważności rozumianej zarówno jako cecha, jak i stan.

Wyniki różnych badań ujawniają, że FMI różni się istotnie od innych narzędzi pod względem zakresu cech psychologicznych odnoszących się do uważności. Tylko FMI zawiera pozycje odnoszące się do istotnych elementów modelu uważności, jakimi są spokój i ciekawość, które jednak mają słabe nasycenie czynnikowe. W związku z tym w 2006 roku powstała skrócona - składająca się z 14 pozycji - wersja kwestionariusza FMI-14 (Walach i in., 2016), w której odrzucono pozycje o ładunku czynnikowym poniżej 0,40. Wartość psychometryczna FMI-14 - sprawdzona na próbce 86 osób bez doświadczenia w medytacji, 117 osób z klinicznymi symptomami oraz 86 z doświadczeniem w medytacji - okazała się satysfakcjonująca. 
Aktualnie trwają dyskusje dotyczące trafności teoretycznej modelu zakładanego w FMI:

1. jednoczynnikowa (Buchheld i in., 2001),

2. dwuczynnikowa: obecność i akceptacja (Kohls, Sauer, Walach, 2009),

3. czteroczynnikowa: uważna obecność, nieosądzająca akceptacja, otwartość na doświadczenie, wgląd (Walach i in., 2006; polska adaptacja: Radoń, 2017b).

Procedura adaptacyjna i walidacyjna FMI przeprowadzona w Polsce (Radoń, 2017b) na populacji nieklinicznej ( $N=578: 128$ uczniów Zespołu Państwowych Szkół Plastycznych w Krakowie w wieku od 15 do 19 lat oraz 450 studentów Uniwersytetu Papieskiego Jana Pawła II w Krakowie w wieku od 20 do 50 lat) zakończyła się sukcesem. Uzyskane rezultaty potwierdzily rzetelność i trafność stosowania stworzonej metody badawczej w stosunku do osób w wieku od 15 do 50 lat. W badaniach polskich potwierdzono trafność danych empirycznych do wszystkich modeli. Przy czym w przypadku osób starszych (od 20 do 50 lat) najlepszym dopasowaniem charakteryzował się model jednoczynnikowy, a w przypadku młodszych (od 15 do 19 lat) - dwuczynnikowy.

Należy podkreślić, że podobne dopasowanie danych empirycznych do różnych modeli uzyskano w przypadku MAAS. Okazało się bowiem, że model jednoczynnikowy był trafniejszy w stosunku do osób w wieku od 20 do 50 lat, a dwuczynnikowy - w odniesieniu do osób w wieku od 15 do 19 lat. Oznaczałoby to, że wiek może stanowić ten czynnik, który decyduje o trafności modelu uważności rozumianej zarówno jako cecha (MAAS), jak i stan (FMI). Jednak brak badań replikacyjnych dotyczących osób od 15. do 19. roku życia nie pozwala na wyciąganie bardziej konkluzywnych wniosków.

\section{FIVE FACET MINDFULNESS QUESTIONNAIRE (FFMQ)}

Ujawnione powiązania między zaprezentowanymi narzędziami do pomiaru uważności prowadzą do istotnych pytań dotyczących trafności pomiaru uważności: czy mierzą one ten sam konstrukt psychologiczny czy też konstrukty odmienne? Co oznacza pojęcie uważności, do którego sumarycznie odnoszą się wszystkie stworzone narzędzia? Odpowiedzi na te pytania poszukiwała Ruth Baer z zespołem (Baer, Smith, Hopkins, Krietemeyer, Toney, 2006), podejmując badania porównawcze $\mathrm{z}$ wykorzystaniem pięciu kwestionariuszy (trzech opublikowanych: FMI, MAAS i KIMS oraz dwóch nieopublikowanych, tj. podobnego w swojej strukturze do KIMS Cognitive Affective Mindfulness Scale (CAMS) i Mindfulness Questionnaire (MQ), wykorzystywanego $\mathrm{w}$ pracy z pacjentami psychotycznymi. Przeprowadzona na dużej próbie studentów analiza czynnikowa nad wszystkimi pozycjami pochodzącymi z pięciu kwestionariuszy wskazywała na pięcioczynnikową strukturę Five Facet Mindfulness Questionnaire (FFMQ), przy czym na samym początku wyjaśniała jedynie 33\% wariancji (przyczyną mógł być brak zaawansowania osób badanych w medytacji). W związku z tym w dalszych pracach walidacyjnych wybrano te pozycje $(N=39)$, które najsilniej korelowały wewnątrz czynników (zastosowanie rotacji Varimax, która zakłada maksymalną niezależność czynników): (1) obserwacja, (2) nieosądzanie, (3) niereaktywność, (4) opisywanie, (5) świadome działanie (dotyczy to jedynie tych osób, które mają duże doświadczenie medytacyjne; Grossman, Niemann, Schmidt, Walach, 2004). Była to ta sama struktura czynnikowa co w KIMS (Baer, 2003), z dodatkiem czynnika niereaktywność.

Prowadzone badania walidacyjne (Baer i in., 2006; polska adaptacja: Radoń, 2014b), tym razem na próbce osób z dużym zaawansowaniem w medytacji (19\% osób badanych miało 10 albo więcej lat doświadczenia medytacyjnego), miały zweryfikować istotność powiązań między poziomem medytacji a uważnością. Okazało się, że jedynie dwa czynniki uważności (obserwacja i niereaktywność) wiążą się z zaawansowaniem w medytacji, przy 
czym obserwacja odgrywa kluczową rolę w początkach zaawansowania, a niereaktywność w późniejszych stadiach.

Pojawiają się pewne sygnały o niektórych problemach psychometrycznych, które dotyczą zarówno rzetelności, jak i trafności FFMQ (por. Radoń, 2014b). Na przykład badania austriackie ujawniły niską rzetelność skali Niereaktywność (por. Tran, Glück, Nader, 2013). W związku z dowodami o ubogim dopasowaniu pełnego zestawu pozycji testowych (39 pozycji) do zakładanych modeli coraz częściej podejmuje się próby skrócenia FFMQ oraz walidacji tych wersji (Bohlmeijer, Klooster, Fledderus, Veehof, Baer, 2011; Tran, Glück, Nader, 2013).

W 2011 roku zespół Bohlmeijera dokonał istotnego skrócenia testu z 39 pozycji do 24 i stworzył holenderską (angielskojęzyczną) wersję Short Form Five Facet Mindfulness Questionnaire (FFMQ-SF; Bohlmeijer i in., 2011). Walidację kwestionariusza przeprowadzono równolegle z walidacją pełnej wersji FFMQ na próbce 376 osób z klinicznymi symptomami depresji i lęku, konstatując, że nie odbiega on od swojego oryginału pod względem zarówno rzetelności (wewnętrzna zgodność: 0,69 < $\alpha<0,90$; stabilność bezwzględna 0,61 $<\mathrm{r}<0,84$ ), jak i trafności. Należy podkreślić, że wyniki badań walidacyjnych ujawniły, iż wewnętrzna zgodność FFMQ zależy od zaawansowania w medytacji (brak zaawansowania: 0,60< < < 0,90; wysokie zaawansowanie: 0,81 < $\alpha<0,94$; por. Baer, Carmody, Hunsinger, 2012).

Prowadzone w wielu krajach badania walidacyjne nad obiema wersjami FFMQ potwierdzają zasadniczo trafność modelu pięcioczynnikowego (Dundas, Vøllestad, Binder, Sivertsen, 2013 - Norwegia; Heeren, Douilliez, Peschard, Debrauwere, Philippot, 2011 - Francja; Hou, Wong, Lo, Mak, Ma, 2013 - Chiny; Sugiura, Sato, Ito, Murakami, 2012 - Japonia; Veehof, ten Klooster, Taal, Westerhof, Bohlmeijer, 2011 - Holandia). Niektóre z badań ujawniają jednak, że w przypadku pewnych grup osób badanych trafniejszy jest model czteroczynnikowy, bez skali Obserwacja (Cebolla i in., 2012 - Hiszpania; Dundas i in., 2013 - Norwegia; Sugiura i in., 2012 - Japonia; Tran, Glück, Nader, 2013 - Austria). Wyniki badań walidacyjnych potwierdzają też lepsze dopasowanie danych empirycznych do modeli niehierarchicznych u osób, które mają duże doświadczenie medytacyjne (Grossman i in., 2008). Osoby niezaawansowane w medytacji trafniej diagnozuje model jednoczynnikowy albo pięcioczynnikowy hierarchiczny, tj. skorelowany (por. Grossman i in., 2008).

Przeprowadzone w Polsce badania walidacyjne polskiego tłumaczenia FFMQ (Pięciowymiarowy Kwestionariusz Uważności; por. Radoń, 2014b) i SF FFMQ (Skrócona Wersja Pięciowymiarowego Kwestionariusza Uważności; por. Radoń, Rydzewska, 2018) również potwierdziły rzetelność i trafność tego narzędzia, przy czym lepszymi właściwościami psychometrycznymi zdaje się charakteryzować skrócona wersja FFMQ zwłaszcza że w tym przypadku kontrolowano poziom zaawansowania w medytacji $(N=830: 128$ uczniów Zespołu Państwowych Szkół Plastycznych w Krakowie w wieku od 15 do 19 lat; 581 studentów Uniwersytetu Papieskiego Jana Pawła II w wieku od 20 do 50 lat; 175 buddystów ze szkoły Karma Kagyu w wieku od 17 do 63 lat). Uzyskane rezultaty potwierdziły rzetelność stosowania stworzonej metody badawczej $(\alpha=0,68-0,85)$, stabilność (od $r=0,66$ do $r=$ 0,91 ) oraz trafność (pięcioczynnikowy model ortogonalny: $\chi^{2}=1,80 ; \mathrm{GFI}=0,95 ; \mathrm{AGFI}=$ $0,94 ; \mathrm{CFI}=0,94 ; \mathrm{RMSEA}=0,04[0,02-0,06] ;$ PCLOSE $=0,99)$.

\section{MINDSENS}

Interesującą próbę opracowania narzędzia badawczego służącego do pomiaru nasilenia uważności rozumianej jako stan podjął zespół Solera (Soler i in., 2014). Głównym celem projektu było stworzenie takiej miary uważności, która w sposób trafny mogłaby różnicować osoby zaawansowane w medytacji od niezaawansowanych, tj. od niemedytujących lub medytujących jedynie sporadycznie. Zespół przyjął na wstępie, że najlepszą strategią będzie 
wykorzystanie najbardziej znanych i cenionych narzędzi badawczych, które odpowiadałyby ich założonemu celowi ( $\mathrm{z}$ jednej strony w maksymalnie zróżnicowany sposób mierzyły tzw. predyspozycje do uważności, a z drugiej - najbardziej wszechstronnie - efekty praktykowania uważności). W tym celu posłużono się dwoma znanymi narzędziami, jakimi są FFMQ (Grossman, 2011) i Experiences Questionnaire (EQ), który obszernie ocenia postępy stosowania treningów (Soler i in., 2014).

Badania walidacyjne przeprowadzono na dużej próbce, 670 osób $(N=384$ i $N=286)$, z kontrolowanym pomiarem zaawansowania w medytacji (typ medytacji, długość sesji, częstotliwość i długość praktykowania). Wyniki badań ujawniły, że - jak wykazano wcześniej w innych badaniach (Baer i in., 2008) - nie wszystkie czynniki uważności odnoszą się do postępów dotyczących umiejętności uzyskiwanych podczas praktykowania treningów. Czynnikami najbardziej relewantnymi okazały się pozycje ze skal Obserwacja (Observing) i Niereaktywność (Nonreactivity) z FFMQ oraz Decentracja (Decentering) z EQ. Pierwsze dwa czynniki wywierały silny efekt (odpowiednio: $d=0,95 ; p<0,001$ i $d=0,85 ; p<0,001$ ), a trzeci - przeciętny $(d=0,72 ; p<0,001)$.

Wyniki przeprowadzonych analiz statystycznych ujawniły, że wszystkie brane pod uwagę pozycje w $82,3 \%$ istotnie odróżniają osoby medytujące codziennie $(N=121)$ od niemedytujących lub medytujących sporadycznie $\left(r=0,624 ; \lambda=0,610 ; \chi^{2}=194,36 ; p<0,001\right)$. Wskaźnikami najtrafniej oceniającymi jakość treningów okazały się częstotliwość i długość czasu praktykowania. Oznacza to, że MINDSENS może być z powodzeniem stosowany do pomiaru jakości praktykowania medytacji (zaawansowanie stanu uważności).

Przeprowadzone w Polsce badania walidacyjne (Radoń, 2019, nieopublikowane badania) potwierdziły rzetelność (dokładność mierzenia), jak i trafność (zaawansowanie stanu uważności). Próbę badawczą stanowily dwie grupy osób bez doświadczenia medytacyjnego $(N=406-59,5 \%)$ i z doświadczeniem $(N=344-40,5 \%$ : medytacja buddyjska, medytacja chrześcijańska, uważność, joga, medytacja transcendentalna i inne), kontrolowane pod względem długości praktykowania (poniżej jednego roku, od roku do 10 lat, powyżej 10 lat), częstotliwości praktykowania (sporadycznie, parę razy w tygodniu, codziennie) oraz zaburzeń (osoby zdrowe, osoby z problemami fizycznymi, osoby z problemami psychicznymi). W badaniach walidacyjnych wykazano dobre dopasowanie do trójczynnikowego modelu równorzędnego $(\mathrm{CMIN} / d f=198,97 / 73 ; \mathrm{CFI}=0,957 ; \mathrm{TLI}=0,946 ; \mathrm{RMSEA}=0,058)$ oraz hierarchicznego $(\mathrm{CMIN} / d f=245,11 / 86 ; \mathrm{CFI}=0,948 ; \mathrm{TLI}=0,937$; RMEA $=0,060)$.

\section{SHORT INVENTORY OF MINDFULNESS CAPABILITY (SIM-C)}

Ciekawą propozycję w zakresie poprawy jakości narzędzi badawczych służących do pomiaru nasilenia uważności rozumianej jako stan przedstawili Duan i Li (2016). Dokonując przeglądu metaanaliz oraz badań dotyczących narzędzi badawczych, doszli do wniosku, że kluczowymi czynnikami z FFMQ które oceniają postęp w zakresie praktykowania, są nieosądzanie, świadome działanie i opisywanie (uważność jako umiejętność uzyskiwana podczas praktykowania). Według badaczy pozostałe dwa czynniki FFMQ(obserwacja i niereaktywność) zdają się raczej odnosić bardziej do cechy uważności.

Badacze, przyjmując ostre kryteria metodologiczne, wyodrębnili 12 pozycji z 39 FFMQ (po cztery pozycje na jeden czynnik), które charakteryzowały się bardzo dobrymi właściwościami psychometrycznymi. Przeprowadzona procedura walidacyjna $(N=780)$ ujawniła, że pozycje te wyjaśniają 67,56\% wariancji. Tak stworzony kwestionariusz Short Inventory of Mindfulness Capability (SIM-C) okazał się charakteryzować poprawną zgodnością wewnętrzną oraz powtarzalnością.

Kwestionariusz SIM-C charakteryzował się ponadto dobrą trafnością zbieżną (spójne z założeniami teoretycznymi korelacje z nasileniem depresyjności i lęku). Jak się okazało, 
uzyskane dane empiryczne pasują zarówno do modelu hierarchicznego $(\mathrm{CFI}=0,925$; TLI = 0,903; RMSEA = 0,049), jak i równorzędnego (CFI = 0,925; TLI = 0,903; RMSEA = 0,049). Rzetelność SIM-C została potwierdzona po okresie sześciu miesięcy (satysfakcjonująca struktura czynnikowa oraz zdolność predyktywna).

Przeprowadzone w Polsce badania walidacyjne (Radoń, 2018, nieopublikowane badania) potwierdziły rzetelność (dokładność mierzenia), jak i trafność (podstawowa umiejętność uzyskiwana podczas praktykowania różnych technik medytacji). Próbę badawczą stanowily dwie grupy osób bez doświadczenia medytacyjnego $(N=406-59,5 \%)$ i z doświadczeniem $(N=344-40,5 \%$ : medytacja buddyjska, medytacja chrześcijańska, uważność, joga, medytacja transcendentalna i inne), kontrolowane pod względem długości praktykowania (poniżej jednego roku, od roku do 10 lat, powyżej 10 lat), częstotliwości praktykowania (sporadycznie, parę razy w tygodniu, codziennie) oraz zaburzeń (osoby zdrowe, osoby z problemami fizycznymi, osoby z problemami psychicznymi). W trakcie badań walidacyjnych potwierdzono dobre dopasowanie danych empirycznych do trójczynnikowego modelu równorzędnego $(\mathrm{CFI}=0,973 ; \mathrm{TLI}=0,966 ; \mathrm{RMSEA}=0,050)$ i hierarchicznego $(\mathrm{CFI}=0,960 ; \mathrm{TLI}=$ 0,$951 ;$ RMSEA $=0,061$.

\section{KENTUCKY INVENTORY OF MINDFULNESS SKILLS (KIMS)}

Kwestionariusz Kentucky Inventory of Mindfulness Skills (KIMS; Baer, Smith, Allen, 2004) to kolejny kwestionariusz do pomiaru specyficznych umiejętności (ang. skills), które zidentyfikowała Marcia Linehan (1993) podczas swoich badań dotyczących efektywności psychoterapii opartej na uważności, skierowanej do osób z zaburzeniami osobowości z pogranicza (borderline), tj. Dialectical Behaviour Therapy (DBT). Celem Linehan było zastosowanie wybranych elementów uważności oraz interwencji behawioralnych w taki sposób, aby były efektywne w terapii osób z borderline. Stworzony na tej podstawie kwestionariusz obejmuje 39 pozycji, które odnoszą się do codziennych umiejętności a tworzą cztery czynniki: (1) obserwacja wrażeń cielesnych,(2) akceptacja bez osądzania, (3) opisywanie doznań, (4) świadome działanie. Tak opracowany KIMS jest przydatny do pomiaru nasilenia zaburzeń osobowości, zdolności do podjęcia ćwiczeń czterech umiejętności oraz oceny postępów terapii.

Przeprowadzone badania walidacyjne (Baer i in., 2004) wykazały, że KIMS charakteryzuje się dobrymi właściwościami psychometrycznymi, tj. zgodnością wewnętrzną $(0,83<a<0,91)$, stabilnością bezwzględną $0,65<r t t<0,86)$ oraz trafnością wewnętrzną i zewnętrzną. Pozycje skali tworzą cztery czynniki (obserwacja, akceptacja, opisywanie, świadome działanie), a dane empiryczne charakteryzują się dobrym dopasowaniem do modelu czteroczynnikowego $(\mathrm{CFI}=0,95 ; \mathrm{RMSEA}=0,07[0,05-0,08])$. Brak jest polskiej walidacji.

\section{JAKOŚCIOWY POMIAR UWAŻNOŚCI}

Pewną pomoc w uporządkowaniu rozumienia i pomiaru uważności stanowią badania jakościowe. Jedne $\mathrm{z}$ ciekawszych zrealizował Chris Mace (2006), który badał doświadczonych trenerów uważności, mających za sobą duże doświadczenie medytacyjne $(N=6)$. Naukowiec przeprowadził szeroko zakrojoną dyskusję między nimi. Najpierw nagrał ich dyskusję 
na nośnikach audio, a potem poddał nagranie procedurze eksploracyjnej, podczas której wyodrębnił istotne wymiary doświadczenia medytacyjnego.

Porównując zakres ujawnionych podczas badań jakościowych obszarów doświadczeń medytacyjnych do tych zakładanych $\mathrm{w}$ narzędziach ilościowych, należy stwierdzić, że w wielu aspektach nie odbiegają one od siebie. Dotyczy to szczególnie takich aspektów jak:

1. inkluzyjność uwagi,

2. jednoprzedmiotowość uwagi, a równocześnie brak selektywności,

3. spokój,

4. akceptacja,

5. niereaktywność,

6. pełne zaangażowanie w doświadczenie (Mace, 2006, 2008).

Wyniki badań jakościowych ujawniają również te aspekty, w których ilościowy pomiar kwestionariuszowy odbiega od pomiaru jakościowego. Dokonuje się to najczęściej w taki sposób, że zidentyfikowane podczas badań jakościowych obszary doświadczeń medytacyjnych występują w sposób rozproszony w różnych narzędziach ilościowych (Mace, 2006, 2008):

1. decentracja, czyli dezidentyfikacja z własnych myślami (FMI, TMS),

2. spontaniczność działań powiązana ze świadomym działaniem (KIMS, CAMS, FFMQ,

3. ciągłość uwagi (MAAS, FMI, TMS),

4. rozwój umiejętności jako konsekwencja praktykowania (tylko FMI),

5. dostrojenie do innych (badania jakościowe, FMI),

6. rozwój współczucia i miłości wobec innych (badania jakościowe),

7. nietrwałość (FMI),

8. metapoznanie (FMI).

Podsumowując wyniki analiz dotyczących porównania ilościowych i jakościowych metod pomiaru, należy stwierdzić, że wyodrębnione podczas badań jakościowych obszary doświadczenia medytacyjnego są w narzędziach ilościowych wysoce rozproszone. Wyniki przeprowadzonych analiz zdają się wskazywać na konieczność zwrócenia większej uwagi na spójność między konstruktami psychologicznymi zakładanymi w narzędziach ilościowych a wynikającymi $z$ analiz jakościowych.

\section{PODSUMOWANIE}

Ponieważ istnieje sporo niejasności dotyczących rozumienia pojęcia uważności, istnieje też potrzeba ich spójnego przedstawienia, którą artykuł ten podejmuje. Różnorodność konstruktów psychologicznych mierzonych odmiennymi narzędziami badawczymi wynika $\mathrm{z}$ jednej strony $\mathrm{z}$ braku jednoznaczności definicji uważności (por. Baer, 2019; Medvedev $\mathrm{i}$ in., 2017), $\mathrm{z}$ drugiej zaś strony - $\mathrm{z}$ różnorodności stosowanych protokołów treningowych oraz terapeutycznych (Tran, Glück, Nader, 2013). Wynikają stąd liczne problemy przy interpretacji wyników badań uzyskiwanych za pomocą tych narzędzi. $Z$ tego względu badacze coraz częściej podejmują więc próby wyróżnienia oraz bardziej precyzyjnego rozdzielenia dwóch odmiennych aspektów uważności, tj. cechy oraz stanu. $Z$ tych samych powodów 
celem niniejszego artykułu był przegląd istniejących miar uważności z uwzględnieniem polskich adaptacji i ukazaniem ich specyfiki.

Wyniki przeprowadzonych analiz dowodzą, że konstrukty mierzone zaprezentowanymi $\mathrm{w}$ artykule narzędziami badawczymi są następujące:

1. stan oraz równocześnie cecha (dezidentyfikacja, nieosądzanie, otwartość na negatywne stany umysłowe, rozumienie wglądowe zorientowane na proces, ciekawość i spokój):

- FMI (Walach i in., 2006; polska adaptacja: Radoń, 2017b),

- FFMQ (Baer i in., 2006; polska adaptacja: Radoń, 2014b),

- FFMQ-SF (Bohlmeijer i in., 2011; polska adaptacja: Radoń, Rydzewska, 2018);

2. cecha rozumiana jako przeciwieństwo rutynowego, nieświadomego oraz zautomatyzowanego działania: MAAS (Brown, Ryan, 2003; polska adaptacja: Radoń, 2014a);

3. stan rozumiany jako umiejętność uzyskiwana przez praktykowanie albo podczas praktykowania różnych technik medytacyjnych:

- osiągnięcie podstawowych umiejętności medytacyjnych przez systematyczne i samodzielne praktykowanie różnych technik medytacyjnych: SIM-C (Duan, Li, 2016; polska adaptacja: Radoń, 2019, nieopublikowane badania);

- osiągnięcie zaawansowania w uważności przez systematyczne oraz długotrwałe praktykowanie różnych technik medytacyjnych: MINDSENS (Soler i in., 2014; polska adaptacja: Radoń, 2019, nieopublikowane badania);

- osiągnięcie specyficznych umiejętności po odbyciu trwającego określony czas (np. po ośmiu tygodniach MBSR), pod kierunkiem certyfikowanego nauczyciela, treningu medytacyjnego: TMS (Lau i in., 2006; polska adaptacja: Radoń, Górska, 2020, nieopublikowane badania);

- osiągnięcie specyficznych umiejętności, które są przydatne do celów psychoterapeutycznych: KIMS (Baer i in., 2004; brak polskiej adaptacji).

Patrząc syntetycznie, należy stwierdzić, że główną przyczyną uzyskiwania niespójnych rezultatów badawczych jest brak rozróżnienia między stanem (odmiennie rozumianymi umiejętnościami zdobywanymi podczas praktykowania różnych technik medytacyjnych) a cechą. Widać to szczególnie w przypadku dwóch kwestionariuszy, które wykazują bardzo zróżnicowaną strukturę czynnikową, tj. jedno-, dwu- lub czteroczynnikową w FMI (Walach i in., 2006; polska adaptacja: Radoń, 2017b) oraz cztero- lub pięcioczynnikową w FFMQ (Baer i in., 2006; polska adaptacja: Radoń, 2014b) i w jego skróconej wersji, tj. FFMQ-SF (Bohlmeijer i in., 2011; polska adaptacja: Radoń, Rydzewska, 2018).

Chyba najmniej problemów występuje w przypadku pomiaru cechy uważności. Wyniki badań w tej dziedzinie okazują się relatywnie spójne oraz dowodzą, że cecha uważności ma strukturę jednoczynnikową (MAAS: Brown, Ryan, 2003). Chociaż i tutaj pojawiają się pewne wątpliwości. W polskich badaniach bowiem wprawdzie potwierdzono jednoczynnikową strukturę MAAS, jednak tylko u osób w wieku od 20 do 50 lat (Radoń, 2014a). Dla osób w wieku od 15 do 19 lat bardziej trafny okazał się model dwuczynnikowy. Oznaczałoby to, że wiek może stanowić ten czynnik, który w istotnym stopniu wpływa na trafność pomiaru uważności rozumianej nie tylko jako cecha (MAAS: Radoń, 2014a), ale i stan (FMI: Radoń, 2017b). Ponieważ brak jest jednak badań replikacyjnych, nie należy wyciągać bardziej konkluzywnych wniosków.

Prawdopodobnie kluczową przyczyną istnienia wielu niespójności dotyczących definiowania pojęcia uważności jest więc nie koncepcja uważności jako cechy, ale jako stanu. 
Wydaje się, że przełomowym odkryciem dotyczącym rozumienia pojęcia uważności jako stanu może być rozróżnienie dwóch odmiennych jej aspektów, tj. zdolności do osiągania podstawowych umiejętności, uzyskiwanej podczas systematycznego i samodzielnego praktykowania różnych technik medytacji (SIM-C: Duan, Li, 2016; polska adaptacja: Radoń, 2018, nieopublikowane badania) oraz - osiaganego na skutek długotrwałego praktykowania różnych technik medytacji - stanu zaawansowania w uważności (MINDSENS: Soler i in., 2014; polska adaptacja: Radoń, 2019, nieopublikowane badania). Wprawdzie dwa inne testy identyfikują odmiennie rozumiane stany uważności jako zdolność do osiągnięcia specyficznych umiejętności (TMS - po praktykowaniu przez określony czas treningów medytacyjnych albo KIMS - potrzebnych do dojrzałego funkcjonowania psychologicznego i społecznego), jednak są one mniej konluzyjne, dotyczą bowiem wyspecjalizowanych umiejętności.

Wydaje się więc, że odróżnienie stanu uważności rozumianego jako podstawowa umiejętność medytacyjna od zaawansowania w dużym stopniu wyjaśnia istnienie wielu niespójności. Ujawnia bowiem, że wyróżnienie tych dwu aspektów stanu uważności mogłoby $\mathrm{w}$ istotnym stopniu poprawić trafność szczególnie tych narzędzi, które mierzą jednocześnie dwa aspekty uważności, tj. cechę i stan (FMI, FFMQ i jego skrócona wersja, tj. FFMW-SF).

Pewne wskazówki co do modelu uważności zakładanego w stosowanych obecnie narzędziach badawczych przynoszą wyniki badań jakościowych. Ujawniają one bowiem, że metody ilościowe dokonują pewnej redukcji uważności do takich mechanizmów psychologicznych jak: świadomość wewnętrznych doznań, ciągłość uwagi, akceptacja, nieosądzanie, decentracja, metapoznanie itd., podczas gdy jakościowa analiza opisów doznań osób zaawansowanych w medytacji pokazuje, że uważność wiąże się z o wiele szerszą gamą doświadczeń (Mace, 2008). Wprawdzie narzędzia ilościowe również odnoszą się do tych aspektów, jednak są one rozproszone:

1. MAAS (jeden czynnik): wzrost spokoju i akceptacji doświadczeń;

2. TMS (dwa czynniki): inkluzyjność i nieselektywność uwagi, dezidentyfikacja z myślami;

3. KIMS (cztery czynniki): wzrost poczucia własnej cielesności, inkluzyjność i nieselektywność uwagi, spadek reaktywności, wzrost spokoju i akceptacji doświadczeń;

4. FMI (jeden, dwa lub cztery czynniki): inkluzyjność i nieselektywność uwagi, zawieszenie starań dotyczących potrzeby kontrolowania doświadczeń, dezidentyfikacja z myślami;

5. FFMQ (cztery lub pięć czynników): wzrost poczucia własnej cielesności, inkluzyjność i nieselektywność uwagi, spadek reaktywności, wzrost spokoju i akceptacji doświadczeń;

6. MINDSENS (trzy czynniki): wzrost poczucia własnej cielesności, spadek reaktywności, dezidentyfikacja $\mathrm{z}$ własnymi myślami;

7. SIM-C (trzy czynniki):poprawa poczucia ja,wzrost spokoju i akceptacji doświadczeń.

\section{WNIOSKI I POSTULATY}

$Z$ jednej strony identyfikacja i odróżnienie dwóch aspektów stanu uważności (podstawowe umiejętności medytacyjne i zaawansowanie), a z drugiej strony ujawnienie o wiele szerszej, niż zakładają narzędzia ilościowe, gamy umiejętności zdobywanych podczas praktykowania różnych technik medytacyjnych (decentracja, świadome działanie, ciągłość uwagi, rozwój umiejętności jako konsekwencja praktykowania, dostrojenie do innych, rozwój współczucia 
i miłości wobec innych, zdolności metapoznawcze, nietrwałość) dają nadzieję na możliwość wypracowania w przyszłości bardziej trafnych narzędzi badawczych. Biorąc pod uwagę wyniki badań jakościowych, należy postulować potrzebę stworzenia takich narzędzi badawczych, które nie dokonywałyby redukcji pojęcia uważności. Stworzenie takich narzędzi mogłoby prawdopodobnie przyczynić się do poprawy trafności badań dotyczących efektywności praktykowania różnych technik medytacyjnych.

Odkryte prawidłowości (doświadczenie medytacyjne nie zależy od długości sesji, ale od systematyczności praktykowania oraz szeroko rozumianej wiedzy dotyczącej uważności) sugerują potrzebę dokonania rewizji wszystkich stosowanych do dzisiaj narzędzi pomiarowych. Celem takiej rewizji będzie stworzenie narzędzi trafniej oceniających efektywność praktykowania różnych strategii medytacyjnych.

Aktualnie najważniejszym zadaniem badaczy jest opracowanie takich strategii interwencji opartych o uważność, aby z jednej strony były optymalne (krótkie, tanie, a równocześnie efektywne), a z drugiej - umożliwiały w sposób trafny identyfikację czynników wpływających na poprawę zdrowia. Optymalność oznacza takie opracowanie protokołów interwencji opartych o uważność, aby były one zarówno efektywne w stosunku do szerokiej gamy zaburzeń (oraz trenowanych umiejętności), jak i ograniczały czas treningów potrzebny do uzyskania poprawy zdrowia albo określonych umiejętności (efektywność nie zależy od długości sesji). $Z$ kolei trafność oznacza możliwość precyzyjnej identyfikacji czynników wpływających na efektywność (rzetelność i trafność pomiaru efektów). 


\section{BIBLIOGRAFIA}

Baer, R. A. (2003). Mindfulness training as a clinical intervention: a conceptual and empirical review. Clinical Psychology: Science and Practice, 10, 125-143. D0I: 10.1093/clipsy.bpg015

Baer, R. A. (2019). Assessment of mindfulness by self-report. Current Opinion in Psychology, 28, 42-48. D0I: 10.1016/j.copsyc.2018.10.015

Baer, R. A., Carmody, J., Hunsinger, M. (2012). Weekly change in mindfulness and perceived stress in a mindfulness-based stress reduction program. Journal of Clinical Psychology, 68, 755-765. D01: 10.1002/jclp.21865

Baer, R. A., Smith, G. T., Allen, K. B. (2004). Assessment of mindfulness by self-report: The Kentucky Inventory of Mindfulness Skills. Assessment, 11, 191-206. D0I: $10.1177 / 1073191104268029$

Baer, R., Smith, G. T., Hopkins, J., Krietemeyer, J., Toney, L. (2006). Using self-report assessment to explore facets of mindfulness. Assessment, 13, 27-45. D0I: $10.1177 / 1073191105283504$

Baer, R., Smith, G. T., Lykins, E., Button, D., Krietemeyer, J., Sauer, S., Walsh, E., Duggan, D., Williams, J. M. G. (2008). Construct validity of the five facet mindfulness questionnaire in meditating and nonmeditating samples. Assessment, 15, 329-342. D0I: 10.1177/1073191107313003

Banich, M. T. (2004). Cognitive Neuroscience and Neuropsychology. Boston: Houghton Mifflin.

Bitbol, M., Petitmengin, C. (2013). A defense of introspection from within. Constructivist Foundation, 8, 269-279. Pobrane z: https://constructivist.info/8/3/269

Bodhi, B. (1984). The noble eightfold path. Kandy, Sri Lanka: Buddhist Publication Society.

Bohlmeijer, E., Klooster, P. M., Fledderus, M., Veehof, M. M., Baer, R. (2011). Psychometric properties of the Five Facet Mindfulness Questionnaire in depressed adults and developing of the Short form. Assessment, 18, 308-320. D0I: 10.1177/1073191111408231

Brown, K. W., Ryan, R. M. (2003). The benefits of being present: Mindfulness and its role in psychological well-being. Journal of Personality and Social Psychology, 84, 822-848. DOI: 10.1037/0022-3514.84.4.822

Buchheld, N., Grossman, P., Walach, H. (2001). Measuring mindfulness in insight meditation (vipassana) and meditation-based psychotherapy: The development of the Freiburg Mindfulness Inventory (FMI). Journal for Meditation and Meditation Research, 1, 11-34. D0I: 10.2307/1411318

Cahn, B. R., Polich, J. (2006). Meditation states and traits: EEG, ERP, and neuroimaging studies. Psychological Bulletin, 132, 180-211.D01:10.1037/0033-2909.132.2.180

Cebolla, A., García-Palacios, A., Soler, J., Guillen, V., Baños, R., Botella, C. (2012). Psychometric properties of the Spanish validation of the Five Facets of Mindfulness Questionnaire (FFMQ). European Journal of Psychiatry, 26, 118-126. D0I: 10.4321/S0213-61632012000200005

Cebolla, A., Luciano, J. V., DeMarzo, M. P., Navarro-Gil, M., Campayo, J. G. (2013). Psychometric properties of the Spanish version of the mindful attention awareness scale (MAAS) in patients with fibromyalgia. Health and Quality of Life Outcomes, 11(6), 1-7. D0I: 10.1186/1477-7525-11-6

Chambers, R., Gullone, E., Allen, N. B. (2009). Mindful emotion regulation: an integrative review. Clinical Psychology Review, 29, 560-572. D0I: 10.1016/j. cpr.2009.06.005

Duan, W., Li, J. (2016). Distinguishing dispositional and cultivated forms of mindfulness: Item-level factor analysis of Five Facet Mindfulness Questionnaire and Construction of Short Inventory of Mindfulness Capability. Frontiers in Psychology, 7(1348), 1-11. D0I: 10.3389/fpsyg.2016.01348

Dundas, I., Vøllestad, J., Binder, P.-E., Sivertsen, B. (2013). The Five Factor Mindfulness Questionnaire in Norway. Scandinavian Journal of Psychology, 54, $250-260$. DOI: $10.1111 /$ sjop. 12044

Fox, K. C. R., Nijeboer, S., Dixon, M. L., Floman, J. L., Ellamil, M., Rumak, S. P., Sedlmeier, P., Christoff, K. (2014). Is meditation associated with altered brain structure? A systematic review and meta-analysis of morphometric neuroimaging in meditation practitioners. Neuroscience and Biobehavioral Reviews, 43, 48-73. D0I: 10.1016/j.neubiorev.2014.03.016

Galante, J., Galante, I., Bekkers, M.-J., Gallacher, J. (2014). Effect of kindness-based meditation on health and well-being: a systematic review and meta-analysis. Journal of Consulting and Clinical Psychology, 82, 1101-1114. D0l: 10.1037/a0037249

Grossman, P. (2008). On measuring mindfulness in psychosomatic and psychological research. Journal of Psychosomatic Research, 64, 405-408. D0I: 10.1016/j. jpsychores.2008.02.001

Grossman, P. (2011). Defining mindfulness by how poorly I think I pay attention during everyday awareness and other intracTabela problems for psychology's (re)invention of mindfulness: Comment on Brown et al. (2011). Psychological Assessment, 23, 1034-1040. D0l: 10.1037/a0022713

Grossman, P., Niemann, L., Schmidt, S. S., Walach, H. (2004). Mindfulness-based stress reduction and health benefits. A meta-analysis. Journal of Psychosomatic Resources, 57, 35-43. D0I: 10.1016/50022-3999(03)00573-7

Heeren, A., Douilliez, C., Peschard, V., Debrauwere, L., Philippot, P. (2011). Cross-cultural validity of the Five Facets Mindfulness Questionnaire: adaptation and validation in a French-speaking sample. Revue Européenne de Psychologie Appliquée, 61(3), 147-151. D0l: 10.1016/j.erap.2011.02.001

Hou, J., Wong, S. Y-S., Lo, H. H-L., Mak, W. W-S., Ma, H. S-W. (2013). Validation of a chinese version of the Five Facet Mindfulness Questionnaire in Hong Kong and development of a short form. Assessment, 21, 363-371. D0I: 10.1177/1073191113485121

Hölzel, B. K., Lazar, S. W., Gard, T., Schuman-0livier, Z., Vago, D. R., Ott, U. (2011). How does mindfulness meditation work? Proposing mechanisms of action from a conceptual and neural perspective. Perspective on Psychological Science, 6, 537-559. D0I: 10.1177/1745691611419671

Kohls, N., Sauer, S., Walach, H. (2009). Facets of mindfulness - results of an online study investigating Freiburg Mindfulness Inventory. Personality and Individual Differences, 46, 224-230. DOI: 10.1016/j.paid.2008.10.009

Kozhevnikov, M., Louchakova, 0., Josipovic, Z., Motes, M. A. (2009). The enhancement of visuospatial processing efficiency through Buddhist Deity meditation. Psychological Science, 20(5), 645-653. D0I: 10.1111/j.1467-9280.2009.02345.x

Lau, M. A., Bishop, S. R., Segal, Z. V., Buis, T., Anderson, N. D., Carlson, ... Carmody, J. (2006). The Toronto Mindfulness Scale: development and validation. Journal of Clinical Psychology, 62, 1445-1467. D0I: 10.1002/jclp.20326

Linehan, M. M. (1993). Cognitive-behavioral treatment of borderline personality disorder. New York: Guilford Press.

Mace, C. (2006). Long-term impacts of mindfulness on psychological wellbeing: new findings from qualitative research. W: A. Delle Fave (red.), Dimensions of well-being. Research and Intervention (s. 455-469). Mediolan: Franco Angeli.

Mace, C. (2008). Mindfulness and mental health. Therapy, theory and science. New York: Brunner-Routledge. D0I: 10.4324/9780203945919 
Medvedev, 0. N., Krägeloh, C. U., Narayanan, A., Siegert, R. J. (2017). Measuring mindfulness: applying generalizability theory to distinguish between state and trait. Mindfulness, 8, 1036-1046. DOl: 10.1007/s12671-017-0679-0

Radoń, S. (2014a). Walidacja Skali Świadomej Obecności. Studia Psychologica, 14(1), 51-70.

Radoń, S. (2014b). Pięciowymiarowy Kwestionariusz Uważności: Polska adaptacja. Roczniki Psychologiczne, 17, 711-735.

Radoń, S. (2017a). Czy medytacja naprawdę działa? Kraków: WAM.

Radoń, S. (2017b). Fryburski Inwentarz Uważności FIU-14 (polska adaptacja i walidacja Freiburg Mindfulness Inventory). Studia Psychologica, 17(1), 85-100. D0I: 10.21697/sp.2017.17.1.05

Radoń, S. (2018). Kwestionariusz Zdolności do Bycia Uważnym (nieopublikowane badania własne).

Radoń, S. (2019). Kwestionariusz Zaawansowania w Uważności (nieopublikowane badania własne).

Radoń, S. (2020). Co naprawdę działa w medytacji? Wspólny rdzeń i specyfika medytacji. Kraków: WAM.

Radoń, S., Górska, G. (2020). Tottoński Inwentarz Uważności (nieopublikowane badania własne).

Radoń, S., Rydzewska, M. (2018). Validation of the Polish version of the Short Form of the Five Facet Mindfulness Questionnaire. Annals of Psychology, 21, 279-298. DOI: 10.18290/rpsych.2018.21.3-5

Rubia, K. (2009). The neurobiology of meditation and its clinical effectiveness in psychiatric disorders. Biological Psychology, 82, 1-11. D0I: 10.1016/j. biopsych0.2009.04.003

Sedlmeier, P., Eberth, J., Schwarz, M., Zimmermann, D., Haarig, F., Jaeger, S., Kunze, S. (2012). The psychological effects of meditation: a meta-analysis. Psychological Bulletin, 138, 1139-1171. DOI: 10.1037/a0028168

Sugiura, Y., Sato, A., Ito, Y., Murakami, H. (2012). Development and validation of the Japanese version of the Five Facet Mindfulness Questionnaire. Mindfulness, 3 , 85-94. D0I: 10.1007/s12671-011-0082-1

Soler, J., Cebolla, A., Feliu-Soler, A., Demarzo, M. M., Pascual, J. C., Baños, R., García-Campayo, J. (2014). Relationship between meditative practice and self-reported mindfulness: the MINDSENS composite index. PLoS One, 9(1): e86622. D0I: 10.1371/journal.pone.0086622

Sperduti, M., Martinelli, P., Piolino, P. (2012). A neurocognitive model of meditation based on activation likelihood estimation (ALE) meta-analysis. Consciousness and Cognition, 21(1), 269-276. D0l: 10.1016/j.concog.2011.09.019

Tang, Y.-Y., Hölzel, B.K., Posner, M. I. (2015). The neuroscience of mindfulness meditation. Nature Reviews Neuroscience, 16, 213-225. D0I: 10.1038/nrn3916

Tran, U. S., Glück, T. M., Nader, I. W. (2013). Investigating the Five Facet Mindfulness Questionnaire (FFMQ): Construction of a Short Form and evidence of a two-factor higher order structure of mindfulness. Journal of Clinical Psychology, 69, 951-965. D0I: 10.1002/jclp.21996

Vago, D. R., Silbersweig, D. A. (2012). Self-awareness, self-regulation, and self-transcendence (S-ART): a framework for understanding the neurobiological mechanisms of mindfulness. Frontiers in Human Neurosciences, 6(296). D0I: 10.3389/fnhum.2012.00296

Veehof, M. M., ten Klooster, P. M., Taal, E., Westerhof, G. J., Bohlmeijer, E. T. (2011). Psychometric properties of the Dutch Five Facet Mindfulness Questionnaire (FFMQ) in patients with fibromyalgia. Clinical Rheumatology, 30, 1045-1054. D0I: 10.1007/s10067-011-1690-9

Walach, H. (2014). Towards an epistemology of inner experience. W: S. Schmidt, H. Walach (red.), Meditation - Neuroscientific Approaches and Philosophical Implications. Studies in Neuroscience, Consciousness, and Spirituality (s. 7-22). Cham: Springer.

Walach, H., Buchheld, N., Buttenmüller, V., Kleinknecht, N., Schmidt, S. (2006). Measuring mindfulness: The Freiburg Mindfulness Inventory (FMI). Personality and Individual Differences, 40, 1543-1555. D0l: 10.1016/j.paid.2005.11.025

Wallace, B. A. (2006). The attention revolution: Unlocking the power of the focused mind. Boston, MA: Wisdom Publications.

Xue, S. W., Tang, Y-Y., Tang, R., Posner, M. I. (2014). Short-term meditation induces changes in brain resting EEG theta networks. Brain and Cognition, 87(1), 1-6. D0I: 10.1016/j.bandc.2014.02.008 